\title{
Attitude of people towards retention and switching: A study based on Nestle brand in Pakistan
}

\author{
Muhammad Amin khan \\ Department of Management Sciences, The Islamia University of Bahawalpur, Pakistan \\ Email: Aminkhan221@yahoo.com
}

Muhammad Raheel

Department of Management Sciences, The Islamia University of Bahawalpur, Pakistan

Email: Choudhryraheel@gmail.com

\section{Muhammad Saqib Chughtai}

Department of Management Sciences, The Islamia University of Bahawalpur, Pakistan

Email: Saqibchughtai84@yahoo.com

\section{Suftain Raza}

Department of Management Sciences, The Islamia University of Bahawalpur, Pakistan

Email: suftainraza@yahoo.com

\author{
Muhammad Rizwan \\ Lecturer, Department of Management Sciences \\ The Islamia University of Bahawalpur, Pakistan \\ E-mail: rizwan.arshad@iub.edu.pk
}

Accepted: June 19, 2014

Doi:10.5296/ jpag.v4i2.5842 URL: http://dx.doi.org/10.5296/ jpag.v4i2.5842

\begin{abstract}
Intention to change from a product/service to a different ends up in change behaviour . This
\end{abstract}


behaviour may end up in a very major decrease within the sales revenue that successively can end in a large decrease in profits. The aim of this study is to visualize the change intention of the people because of totally different multiple factors. The character of this analysis is descriptive. All variables have important impact on change intention. The result shows that client satisfaction and client loyalty have negative impact on switching intention. And every factor has positive impact on switching intention. The results show that as loyalty and satisfaction of client will increase the intention to switching decreases. On the opposite hand increase in worth, company name, trust and word of mouth lead to a rise in change intention. The study was focused primarily in a city and therefore the respondents were primarily below the age of thirty.

Keywords: corporate reputation, customer loyalty, trust

\section{Introduction}

Building long lasting relations with customers has become an important strategy for most organizations in today competitive markets. Customers engineered intention to switch from one organization to a different if their wants don't seem to be glad. Companies will raise client satisfaction by increasing the remuneration that they're providing with the merchandise or services. To keep aloof from the shift of shoppers to alternative organizations relationship marketing is applied since selling actions that capture, develop, sustain and enhance client relationship with the business. Many companies have establish relationship selling programs to push client loyalty toward their product and services and retain the shoppers to stay aloof from shift. 2 factor theory of customer satisfaction custom-made from Fredrick Gerhard Herzberg applied to facilitate establish and theorize antecedent issues are known within the 2 factor theory, "hygiene" factors and "satisfiers". The first factors Hygiene factors are those characteristics that are expected by the customers as least attainable necessities. In need of hygiene factors can direct towards disappointment whereas having them won't essential to develop client satisfaction. Once the client decides to change to the other organization hygiene factors play the role of resolution barrier within the relationship between patrons and sellers. New client acquisition is way costly procedure than retentive your regular customers. The wholes should be up to the standards thus your customers won't move towards the other alternatives. Overall service satisfaction is beneficial in rising customer's intentions to remain with the service supplier. If you're existing client switches from your organization to different organization a lot of price is going to be required to achieve the new customers. This can be necessary for each organization to take care of its existing customers as a result of these customers is the key customers of your organization. Organizations ought to specialize in the requirements of shoppers that what they need, if company fulfills the requirements economically then these customers become loyal and not even think of switching. If associate existing client of your company thinks to switch from your company then its failure of your company. At some level the corporate need to improve the potency and effectiveness of product or services. Switching is

that 
the state once the client become wholly unhappy from the 2014, Vol. 4, No. 2

discontentment happens once the promoting make a case for that client retention, not simply client gaining, is crucial for service companies. While service quality, association quality, and normally service satisfaction area unit useful in increasing shopper's intentions to stay on with a corporation. Corporations need to invest once more to grab the shoppers if the shoppers switches. Finance on the new client to retain them could be a high price activity. "Perceived service quality has been thought of as associate approach towards decoding superiority of the service" (Zeithaml \& Bitner, 2000). Thus defection of customers from their current organization could be an indication to worry about. High service quality to client provides a corporation to tell apart their position in competitive markets and to retain the shoppers. Understanding client switch behaviour is critical as a result of a client's switch behaviour ends up in the loss of the longer term financial gain stream from that customer. It is terribly very important to stay in mind the switching intentions of the shoppers; your firm doesn't have any weaknesses so the shoppers think of shift. The aim of this analysis is to check the factors that influence on the shoppers and build their intention to modify. That why their intention of shift to a different organization happens within the mind of consumers is there any deficiency within the services or merchandise that we are providing. Relational attachment activities by an organization (incentive) might influence customer's value perceptions (organism) that in response might modification their purchasing behaviors (response). There are completely different variables that are the rationale of the switching of the client; they're word of mouth, high price, trust, loyalty and customer satisfaction.

Word of mouth is that the main issue of switching intention of the shoppers, if the negative word of mouth is created it creates shift of the shoppers and if the individuals admire regarding the merchandise and build positive word of mouth that proves sensible for company. High value conjointly effects the actions of person whether or not to remain with the organization or to modify to a different organization. Collaborate name conjointly proves valuable for the organization and might retain the shoppers, if the name of organization is great then the client never thinks of shift to a new organization, and if the name of collaborate isn't up to the standards then the shoppers should place confidence in the switching. Trust is the variable that helps in manufacturing the long run relationship with the organization, trust within the organization is that the image of loyalty of the client. Loyal customers are the real investors during an organization. Loyalty is that the state once the buyer repurchases the merchandise over and yet again. In spite of the economic connectedness of client nature to modify suppliers, there has not nevertheless been a scientific investigation of the question on however way perceived company name (i.e. client-based company reputation) and customer satisfaction influence shift intentions. Chakravarty et al. (2004) "The study underscores the well-built significance of associations in retentive loyal customers and decreasing switching behavior". "By linking shift expenses to client loyalty, this study shows that potential shoppers UN agency area unit stopped from shift might retaliate by harmful spoken (WOM activities" (Jones et al., 2002, 2007; Maute and Forrester, 1993). 
Effective advertise is additionally a effective variable for switch from one organization to a different, if the advertise is effective then the shoppers won't switch to another organization.

\section{Literature Review:}

\subsection{Switching Intention:}

Switching intention is that the state that arises once the performance subsided than the expectations. "One of the main reasons why the buyer switches from provider is service failure" (Keaveney, 1995). "Switching from provider has varied harmful effects on the corporate, the market share is reduced, gain is reduced, and negative word of mouth become increased" (Lewis and Spyrakopoulos, 2001; Broderick et al., 2000). The position of recovery processes has examined aspects of consumer switching intentions. Wirtz and Mattila (2004) found that authorisation and return results on client responses for shifting a service provider. Within the same approach, Boshoff and Leong (1998) state the impact of authorisation and fast actions measure positively related to client loyalty and repatronage. Apace varied and developing technology and lift within the range of product and services caused a rise in competition. So, it's necessary for firms to acknowledge customers, their preferences, higher cognitive process processes the lifetime of their relationships so as to draw in and grasp the shoppers during this aggressive setting. "As long run relationships between the businesses and their customers facilitate the businesses to boost and sustain profit" (Reichheld and Sasser, 1990), client retention becomes a necessary topic. However, people, in many cases, might got to or wish to vary their typical brands, stores and repair suppliers. As a result, the companies, that don't want to drop their consumers, require knowing the switching reasons and generating strategies against them.

\subsection{Customer Satisfaction:}

Customer satisfaction is by and enormous perspective made supported the apply when shoppers acquire a product or use a service (Fornell, 1992). "Customer satisfaction sometimes suggests that consumer feedback to the case of completion, and shopper call of the glad condition" (Oliver, 1997). There's abundant remuneration for a company from Associate in Nursing magnified client satisfaction Stage. If he client satisfaction will increase than it reduces the prices of promoting and of latest client creation, reduces in operation prices thanks to shopper figure raises, improves the effectiveness of packaging, and enhances business name (Fornell, 1992). The key reason of finding client satisfaction is that the customer's individual thinking's of service quality (Zeithamal \& Bitner, 1996). During this study, we tend to shall describe service quality because the customer's satisfaction or discontentment developed by their data of shopping for and utilization of the service (Parasuraman, Zeithamal, \& Berry, 1988). It is an indication of being glad with a product or a service. Customer Satisfaction is that the analysis of the expertise to figure with a service provider, and is employed by customers to forecast future expertise (Crosby et al.1990). Customer Satisfaction is tormented by service quality, product quality, price, and connected and individual factors (Zeithaml \& Bitner, 2000). It's secure to mention that glad customers square measure less meant to change to a different organization. If the customer's needs square measure happy by the services than if becomes happy and suppose to buy the 
merchandise another time. That the customers think to stay with the similar organization and to not switch anyplace within the market. Therefore, the given hypothesis is tested.

H1: Customer Satisfaction has a positive effect on switching intention.

\subsection{High price:}

High value is that the second frequent cause why customers switch. Though things for service costs, value deals, and cheap promotional the pilot study shows that the foremost important of those reasons for client change behaviour is high service value. The correlation analysis supports this finding further, with high value because the just one single-item issue among all the classes of service switch reasons. Namkung and Jang (2007); Yuan and Jang (2008). Bansal et al. (2005) additionally all over that quality, low satisfaction, low trust,low commitment and high value do push a client toward switching intention to another organization . Compared with Keaveney's (1995) study of western customers, that finds that top value is that the third most typical reason for change services, customers appears to position additional importance on high value as they'll be additional sensitive to service value or charge. Value is that the highest issue that may attract and might cut back the purchasers from your cooperation. Find your value that attract the purchasers, most of the purchasers don't afford high value so that they switch towards different several of cheap or low value that they will get. Value is about in keeping with the geographical segments, supported the financial gain ranges of region. Consequently, the subsequent hypothesis is tested.

H2: High price has negative effect on switching intention.

\subsection{Word of Mouth:}

Other conclusion of interest is efficacious word of mouth actions, notably suggestion of the service provider to others. We have a tendency to embody this result because it extends the main target of interest to alternative remuneration of holding customers (Rust et al., 1995). We have a tendency to argue that buyers World Health Organization need to sustain a affiliation with a service provider for sentimental reason are potential to put substantial effort during this cause (Harrison-Walker, 2001). Brown et al. (2005). It'd appear that such certificatory behaviour would be like behaviour of customers' affection loyalty sentiments. In similarity, customers World Health Organization thinks that they'll stick with a supplier to avoid prices are additional probable to point out inactive behaviours. Only between five and ten per cent of dissatisfied customers complain once a service breakdown, whereas silent shift and also the succeeding negative spoken is way a lot of common (Dube and Maute, 1996). There square measure each the consequences of the word of mouth, 
positive word of mouth and also the negative word of mouth. The shoppers with the negative word of mouth are that the threat for your organization, he shares his unpleasant expertise with the merchandise or services of and created intentions of others. Whereas the client with the positive word of mouth share his expertise together with his friends, family and created their intentions to get the merchandise or services. This can become the purpose for your organization. Word of mouth happens once the client is happy. Therefore the result obtained from this shows that:

H3: Increase in customer satisfaction increase in WOM.

\subsection{Corporate Reputation:}

"Corporate reputation has been delineated as a social character and a vital and intangible resource which will clearly contribute to a firm's performance and survival" (Hall, 1993; Rao, 1994; Yoon et al., 1993). Aaker (1996) and Rust et al. (2001) explained company name as complete or client equity, and connected the construct with the believability and quality of the firm. "A sensible name will enhance client loyalty, particularly within the retail industry, wherever quality can't be evaluated specifically before purchase" (Andreassen and Lindestad, 1998; Barich and Kotler, 1991; Nguyen and Leblanc, 2001. Wang et al. (2003) suggested that a work name plays an important role in determinant the buying and repurchasing behaviour of consumers. Likewise, an honest company name will strengthen customers' trust and confidence, whereas associate degree unfavourable company name will increase the likelihood of the selection to change (Clemes et al., 2007a).

H4: There is a positive relationship between corporate reputation and switching intention.

\subsection{Customer loyalty:}

Loyalty has been outlined as "a intensely control commitment to rebury or repatronize a favoured product/service once more and once more within the future" (Oliver, 1999, p. 34). Client loyalty has 2 meanings: long-run and therefore the short loyalty (Jones \& Sasser, 1995). Proof that client loyalty makes a corporation additional profitable makes it imperative that complaints and alternative unfavorable behavioural intentions ar handled effectively to ensure the soundness of those relationships (Tax \& Brown 1998a). Aydin and Ozer (2005) and Zeithaml et al. (1996) confirmed that poor client loyalty and unfavourable behavioural intentions are often determined by poor service quality. In general, effective advertising by the competition adds price, captures the eye of potential customers, and enhances client loyalty (Cengiz et al., 2007). The result's reliable with variety of researchers that believe shift prices because the main determinant of behavioural loyalty in client markets (Burnham et al., 2003; Caruana, 2004; Heide and Weis, 1995). With relation to customers, previous 
studies hints that company name exerts associate influence on perceived risk (e.g. Lantos, 1983), and loyalty (Roberts and Dowling, 2002), all of which may completely or negatively have an effect on firm profits. various empirical studies within the context of products and services have shown that client satisfaction features a positive result on totally different variables like client loyalty (e.g. Biong, 1993; Fornell et al., 1996) and recommendation behaviour (e.g. Swan and King Oliver, 1989; Mooradian and King Oliver, 1997; Selnes and Gronhaug, 1997), however that it's a negative result on client shift intention (e.g. Mittal et al., 1998; Hennig-Thurau et al., 2002). Examining the satisfaction-loyalty link becomes still additionalrelevant as a result of solely few disgruntled customers voice their complaints (e.g. Stephens and Gwinner, 1998), creating it difficult for service companies to handle service-delivery issues and prevent from defection. Relationship quality has been absolutely connected to client loyalty (Hennig-Thurau \& Paul Klee, 1997; Roberts, Varki, \& Brodie, 2003). Each relative traits, as well as satisfaction and trust, and shift barriers have vital effects on client loyalty. Customers with semi permanent loyalty don't simply switch to alternative service suppliers, whereas customers with short loyalty defect additional effortlessly once offered a perceived superior various. This study focuses on semi permanent loyalty. It's helpful for service suppliers to determine a relationship with customers the purchasers would really like to retain. During this scenario, it's higher to retain existing customers than recruit recent ones (Ahmad \& Buttle, 2002; Fornell, 199).

H5: Customer Loyalty has positive effect on word of mouth.

\subsection{Trust:}

Trust has been outlined united party basic cognitive process that the opposite party can fulfil his or her wants. In terms of services, trust is that the belief command by a client that the service supplier can offer the service that meets client wants (Anderson\&Weitz, 1989). "Amore general definition of trust is that a celebration has confidence within the honesty and dependableness of his partner "(Morgan \& Hunt, 1994). This definition are often applied in several contexts, along with exchanges of products and services. Doney and Cannon (1997) argue that trust consists of 2 aspects: perceived credibleness and benevolence. There square measure 2 levels of trust, in line with Rauyruen and Miller (2007). At the primary level, the client trusts one explicit sales representative whereas at the second level, the client trusts the establishment.

Trust is a crucial mediating issue between client behaviour before and when getting a product. It will cause long loyalty and strengthen the association between the 2 parties (Singh \& Sirdeshmukh, 2000). Like loyalty, trust may be a special psychological condition that may just occur in bound relationships.

When a client trusts a company, he or she has the arrogance in commission quality and products quality of the organization. Customers United Nations agency trust a company area unit quite possible to be trustworthy to the corporate (Garbarino \& Johnson, 1999). It's 


\section{Macrothink}

conjointly true in contexts of e-commerce (Liao, Palvia, \& Lin, 2006) and e-Government (Lean, Zailani, Ramayah, \&Fernando, 2009).In previous analysis, trust has been conceptualized as antecedent of satisfaction (e.g., Palvia, 2009). During this analysis we tend to have an interest within the direct effects of satisfaction and trust, as parts of relationship quality, on client loyalty. Thus, the subsequent hypothesis is planned.

H6: Trust has a positive effect on customer loyalty.

\section{Hypothesis and Research Model:}

On the basis of above literature review, the current study tests the following hypothesis.

H1. Customer Satisfaction has a positive effect on switching intention.

H2. High price has negative effect on switching intention.

H3. Increase in customer satisfaction increase in WOM.

H4. There is a positive relationship between corporate reputation and switching intention.

H5. Customer Loyalty has positive effect on word of mouth.

H6. Trust has a positive effect on customer loyalty.

H7: Customer loyalty has positive effect on switching intention.

H8: Customer satisfaction has significant positive effect on customer loyalty. 


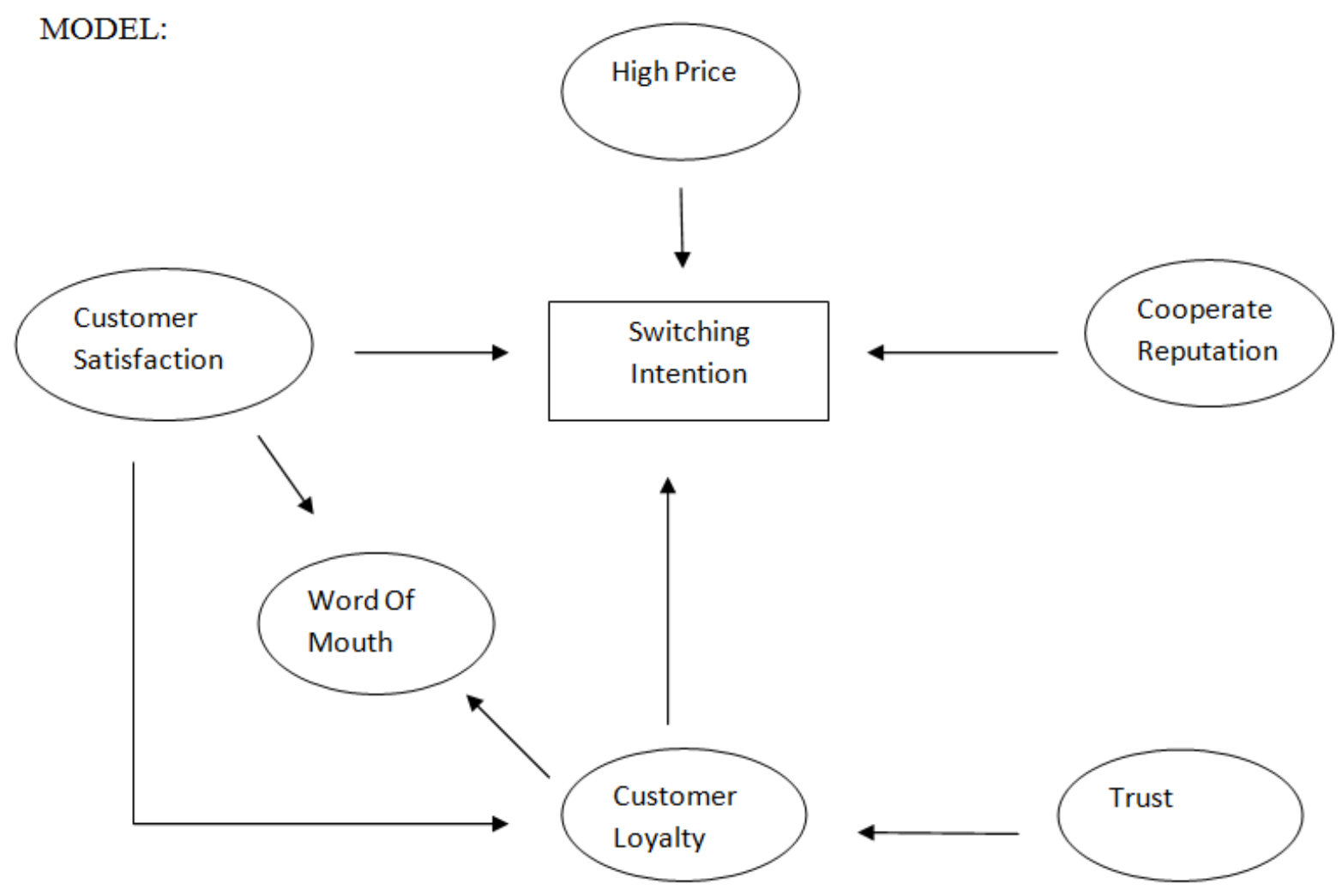

Figure 1

\section{Research Methodology:}

The nature of current analysis is descriptive. Descriptive analysis will be explained as telling one thing, some development or any meticulous state of affairs. Descriptive research that describe this state of affairs rather than decoding and creating judgments (Cresswell 1994). The most important objective of the descriptive analysis is authentication of the developed hypothesis that reflects the recent state of affairs. This sort of analysis provides data concerning gift the current circumstances and concentrate on past or present as an example quality of life during a community or client attitudes towards any selling activity (kumar,2005).

\subsection{Sample/Data:}

In order to collect the statistics for understanding the condition concerning switch intention of the purchasers, a sample of one hundred eighty respondents can inquire to participate within the self-administrated form. The population for the present study is that the users of Nestle juices in Bahawalpur, Pakistan.

The sampling technique that's utilised within the gift study is non-probability sampling technique that's convenience sampling. "Convenience sampling could be a sampling technique that obtains and collect the relevant info from the sample or unit of study that square measure handily out there (Zikmund, 1997). We have a tendency to commonly use 
convenience sampling for the gathering of enormous completed surveys apace and with economy (Lym et al, 2010). To develop the boldness within the survey results and to form these results representatives of the sample, it's considerably very important that an enough amount of participant's area unit chosen. For a fine sample size, a ninety fifth assurance level is employed that indicate there's a five-hitter likelihood that the study will vary from the particular outcome. The ninety fifth confidence level may be a sensible confidence interval or margin of error (Niles, 2006). The researchers usually used the five hundred margin of error in their study and therefore the current study used constant criteria. Thanks to the self-administrated survey technique the response rate for the present study is projected to be seventy fifth. Supported the on top of parameters the sample size is nice for study. It has to be ensured that the sample members posses 2 major qualifications to the participants during a self-administrated survey. 1 st the sample member ought to realize the whole. Second the member ought to use the whole at least once.

We choose their sample from the people of Bahawalpur. To major clusters can target to assemble the sample knowledge from the university students and dealing professionals. They choice of scholars and dealing professionals area unit supported the whole usage because the used the Nestle juice.

\subsection{Instruments and measures:}

The survey instrument of the recent study target 2 major purposes: initial is examining the link of various variables within the acceptance of shift intention. Second to collect the knowledge regarding the various characteristics of respondents which will be accustomed acknowledge the variations in numerous classes.

The survey instrument consists of 2 sections. Section I consists on totally different personal and demographic variables. This section can gather data concerning gender, age, income, education, standing of the population.

Section II contains the latent variables that area unit vital within the current study. These variables represent customer satisfaction, high price, word of mouth, company name, client loyalty and Trust. This section of study is developed supported the past literature and survey used questionnaires. The previous literature and revealed studies were utilised for the adoption of scales of study.

\subsection{Procedure:}

The form was circulated among the one hundred eighty respondents in Bahawalpur. The respondents were chosen supported the standards higher than mentioned. The aim of study and queries were explained to the respondents before giving them questionnaires, in order to they will simply fill the form with the numerous responses. A complete of 164 forms was most well-liked and remaining questionnaire weren't enclosed within the future analysis due to in complete and invalid responses. After collecting the finished questionnaires from the respondents, these questionnaires were coded and entered into SPSS sheet for analysis. 


\subsection{Reliability Analysis:}

All the variables are reliable because the cronback alphas of the variables are above the value of 0.50 Nunnaally (1970) and 0.60 by Moss el al (1998). This shows that all the 31 items were reliable and suitable to compute the opinions of customers towards switching intention.

Table 2: Reliability of Measurements Instrument

\begin{tabular}{|l|l|l|}
\hline Scales & Items & Cronbach Alpha \\
\hline Customer loyalty & 8 & .847 \\
Word of mouth & 5 & .743 \\
High Price & 4 & .782 \\
Trust & 5 & .839 \\
Customer satisfaction & 2 & .599 \\
Corporate reputation & 4 & .791 \\
Switching Intention & 3 & .744 \\
\hline
\end{tabular}

\section{Results and Analysis:}

\subsection{Profile of the respondents:}

Personal and demographic information such as gender, age, income, education level, status are shown below in the table no. 3 .

TABLE 3: Profile of Respondents.

\begin{tabular}{|l|l|l|l|}
\hline Variables & Category & Frequency & Percentage \\
\hline Gender & Male & 125 & 76.2 \\
Female & 39 & 23.8 \\
\hline Age & $\begin{array}{l}15-20 \text { years } \\
20-25 \text { years }\end{array}$ & 51 & 31.1 \\
$25-30$ years & 100 & 61.0 \\
$30-35$ years & 3 & 4.9 \\
$35-40$ years & 1 & 1.8 \\
Above 40 years & 1 & 0.6 \\
\hline
\end{tabular}




\begin{tabular}{|l|l|l|l|}
\hline Income & Below 15000 PKR & 117 & 71.3 \\
& $15000-30000$ PKR & 24 & 14.6 \\
$35000-40000$ PKR & 8 & 4.9 \\
Above 40000 PKR & 14 & 7.9 \\
\hline Education & Matriculation & 4 & 2.4 \\
Inter & 8 & 4.9 \\
Bachelor & 114 & 69.5 \\
Master & 19 & 11.6 \\
MS & 19 & 11.6 \\
\hline \multirow{2}{*}{ Status } & Student & 151 & 92.1 \\
& Employed & 7 & 1.8 \\
\hline
\end{tabular}

\subsection{Hypothesis Testing:}

\subsubsection{Customer satisfaction, High price, corporate reputation, customer loyalty and switching intention:}

The results obtained from the study, the four variables of customer satisfaction, high price, corporate reputation and switching intention have a significant positive relationship with the switching intention. Specifically, the high price has a significant positive relationship with $(\beta=.391)$ and $(\rho<.000)$, this shows that high price adds more than $30 \%$ to switching intention. The regression results of customer satisfaction with the switching intention is also significant negative with $(\beta=-.099)$ and $(\rho<.263)$. The regression results of corporate reputation shows the significant relationship with switching intention $(\beta=.059)$ and $(\rho<.539)$. And the regression results of the variable customer loyalty shows significant negative relationship with the switching intention with $(\beta=-.184)$ and $(\rho<.046)$.

\subsubsection{Word of mouth, customer satisfaction, trust and switching intention:}

The results of the variables word of mouth, customer satisfaction and trust has significant relationship with the customer loyalty. The first variable has the regression results which depicts that the variable trust has significant relationship with the customer loyalty with $(\beta=.394)$ and $(\rho<.000)$. The regression results of the second variable customer satisfaction demonstrates the important relationship with the customer loyalty with $(\beta=.148)$ and $(\rho$ 
$<.050)$. The regression results of the third variable word of mouth also shows significant relationship with the customer loyalty with $(\beta=.272)$ and $(\rho<.000)$.

\subsubsection{Customer satisfaction and word of mouth:}

The regression results confirm the significant positive relationship between customer satisfaction and word of mouth with $(\beta=.324)$ and $(\rho<.000)$. According to these results customer satisfaction contributes more than $32.4 \%$ to the word of mouth.

Table 4: Results of Hypothesis

\begin{tabular}{|c|l|l|l|l|l|l|}
\hline Hypothesis & Model variables & $\begin{array}{l}\text { Estimate } \\
(\beta)\end{array}$ & S.E & C.R (t) & P & Results \\
\hline H1 & $\begin{array}{l}\text { C.S } \\
\text { S.I }\end{array}$ & -.176 & .102 & -2.281 & .024 & supported \\
\hline H2 & $\begin{array}{l}\text { H.P } \\
\text { S.I }\end{array}$ & .379 & .077 & 5.210 & .000 & supported \\
\hline H3 & $\begin{array}{l}\text { C.S } \\
\text { W.O.M }\end{array}$ & .324 & .075 & 4.366 & .000 & supported \\
\hline H4 & $\begin{array}{l}\text { C.R } \\
\text { S.I }\end{array}$ & -.155 & 1.02 & -1.994 & .048 & supported \\
\hline H5 & $\begin{array}{l}\text { C.L } \\
\text { W.O.M }\end{array}$ & 0.544 & 0.070 & 8.261 & .000 & Supported \\
\hline H6 & $\begin{array}{l}\text { C.L } \\
\text { Trust }\end{array}$ & 0.644 & .067 & 10.705 & .000 & Supported \\
\hline C.S & 0.488 & .066 & 7.123 & .000 & Supported \\
\hline
\end{tabular}




\section{Model}

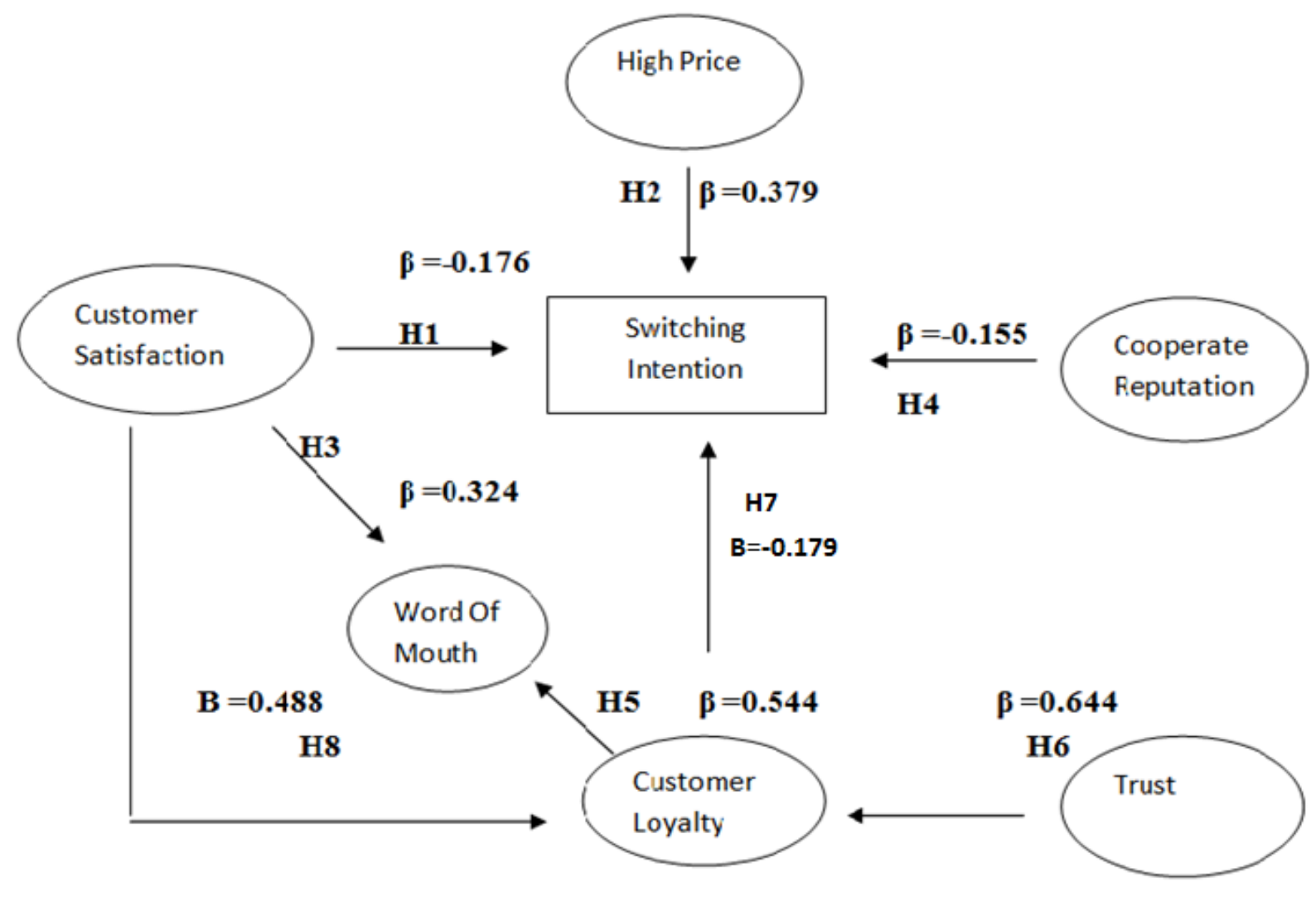

Figure 2

\section{Discussion:}

Switching intention is that the condition that arises once the performances decrease than expectations. Service failure has been found to be one among the key reasons that buyers switch from suppliers (Keaveney, 1995). Change of service suppliers has varied harmful effects on the firm, market share is reduced, and therefore the gain reduces. Client switch from one whole to a different, as a result of the merchandise and services doesn't fulfil the Customer's desires and demands if a worker of a corporation takes pay and he's not glad from his remuneration package then he switches from this company so he be part of the opposite company.

In Pakistan several examples are seen in lifestyle. Several workers are shift from one company to a different as a result of not satisfaction in job. West Pakistan is Associate in nursing good country because of the high consumption of the merchandise and services. Switching intention could be a large drawback in West Pakistan. The Results Obtained from the analysis of Hypotheses and to know the connection between completely different variables. Currently severally we are going to discuss the finding and their implication within the following section. 
The results obtained from current study the four variables of customer satisfaction, high price, company name and switching intention have a major positive relationship with the switching intention. However, the connection between SI and CL is in contrary to the findings of Shin and Kim (2007), who rejected the proposal that higher stage of perceived service quality is said to lower level of shift. Whereas Anton et al. (2007) found that relationship between satisfaction and loyalty is mediate through change prices that could be a part of change barriers. Though the connection between loyalty and change intentions is critical, but it's weak. To conclude, 3 relative factors, namely, quality, satisfaction and trust, considerably predict change barriers and among these, satisfaction is that the strongest predictor. More, these 3 relative factors influence customers' intention to modify that is additionally considerably expected through change barriers. Consequently, these intentions significantly have an effect on client loyalty. Hence, the study reveals the positive vital role contends by the relative factors in predicting client loyalty or discouraging client change. An overall, the results show that change prices confirm change and turn out negative WOM, however solely with low inertia customers. High inertia customers, whose inertias teemed from satisfaction, cared-for keep, gave additional positive WOM, and gave less negative WOM as change prices increase. However, change prices were unrelated to preservation or WOM behaviours for purchasers are indifferent to difficult service suppliers. Within the following sections, we have a tendency to elaborate on these findings

This result can also assist make a case for why Jones et al. (2007) abs initio hypothesized that shift prices gave rise to negative WOM, however didn't discover a big relationship between shift prices and negative WOM. During this study, we discover that high-inertia/satisfied customers should still understand high shift prices. In alternative words, unless a study accounts for inertia, merely relating shift prices to negative WOM could bring about to incomplete or perhaps deceptive results. The results purpose thereto service failure severity contains an important negative relationship with client loyalty within the scenario of selling. As such, clients WHO follow a high severity service failure square measure additional probably to point out signs of low customer loyalty as compared to those that expertise a service failure that they understand to be low severity. The probable negative relationship between company name and shift intention may solely be confirmed in its tendency. The non-significant and weak relationship between company name and shift intention could also be as a result of the very fact that in its current type (including its name), the several power offer company has solely existed for many years and has so had very little chance to develop a robust name.

The present study examines previous circumstances of client loyalty and WOM intention during a written agreement services market by analyzing the role of satisfaction, economic change barriers, social ties, and habits of newspaper subscribers. Results of the empirical study expose that satisfaction and economic change barriers square measure the strongest drivers of client loyalty. Social ties and habits square measure less significant as antecedents of client loyalty. However, social ties square measure the strongest antecedent of WOM intention, followed by satisfaction, so economic change barrier. Change Intention was found to own a major positive relationship with client loyalty. As mentioned earlier, change 
intention is thought to be consumer's value analysis of exchange their current service supplier.

\section{Recommendations and Future research:}

These square measure the results of the study on change intention from Nestle juices within the Bahawalpur.1st of all the client satisfaction and therefore the client loyalty incorporates a sturdy negative result on change intention. The shoppers square measure happy that the intention to modify from the Nestle complete won't be developed. And therefore the customers square measure loyal to the Nestle complete they not even think about change and within the result customer's retention happens.

Secondly, there's high company name of the corporate Nestle that conjointly works to draw in the shoppers, this result depicts that the shoppers square measure extremely will purchase the Nestle juices over different juices. The shoppers have trust within the complete that is made by the promising services of the company. The Nestle has maintained its excellence and conjointly provides the juices in a very giant vary than the other company. The result shows that the folks unaccustomed Nestle complete when victimization the complete generate word of mouth for the complete and results shows the positive word of mouth is created for the corporate, which ends the shoppers to be loyal and attract different customers too. The recommendations square measure these the analysis is conducted on little scale with small sample population. Solely Bahawalpur and specially The Islamia University of Bahawalpur is targeted. Giant portion of our sample size contains students; therefore this result shows the opinion of the young students of university towards the Nestle complete. And restricted variables square measure mentioned. Within the future the analysis are often conducted by finding out the result of different variables on the change intention of the folks. The sample size is often enlarging to check the behaviours of individuals towards the complete. And also specialize in totally different age teams of individuals that the vivid image of the customer's results.

\section{References}

Aaker, D.A. (1996), Managing Brand Equity, The Free Press, New York, NY.

Rust, R.T., Zeithaml, V.A. and Lemon, K.N. (2001), Driving Customer Equity: How Customer Lifetime Value is Reshaping Corporate Strategy, The Free Press, New York, NY.

Andreassen, T.W. and Lindestad, B. (1998), "The effect of corporate image in the formation of customer loyalty”, Journal of Service Research, Vol. 1 No. 1, pp. 82-92.

Aydin, S. and Ozer, G. (2005), "An analysis of antecedents of customer loyalty in the Turkish mobile communication market”, European Journal of Marketing, Vol. 39 Nos 7/8, pp. 910-23.

Ahmad, R., \& Buttle, F. (2002). Customer retention management: A reflection of theory and practice. Marketing Intelligence and Planning, 20(3), 149-161. 
Anderson, E., \&Weitz, B.(1989).Determinants of continuity in conventional industrial channel dyads. Marketing Science, 8 (3), 10-23.

Bansal, H.S., Taylor, S.F. and James, Y.S. (2005), "Migrating to new service provider: towards a unifying framework of consumers' switching behaviours", Journal of Academy of Marketing Science, Vol. 33 No. 1, pp. 96-115.

Brown, S. W. (1998a). Recovering and learning from service failures. SloanManagement Review, 40, 75-88.

Beatty, S.E. (2000), “Switching barriers and repurchase intentions in services”, Journal of Retailing, Vol. 76 No. 2, pp. 259-74.

Barich, H. and Kotler, P. (1991), “A framework for marketing image management”, Sloan Management Review, Winter, pp. 94-104.

Biong, H. (1993), "Satisfaction and loyalty to suppliers within the grocery trade", European Journal of Marketing, Vol. 27 No. 7, pp. 21-38.

Brown, T.J., Barry, T.E., Hall, R. (1993), “A framework linking intangible resources and capabilities to sustainable advantage", Strategic Management Journal, Vol. 14 No. 8, pp. 607-18.

Burnham, T.A., Frels, J.K. and Mahajan, V. (2003), "Consumer switching costs: a typology, antecedents, and consequences", Journal of the Academy of the Academy of Marketing Science, Vol. 31 No. 2, pp. 109-26.

Chakravarty, S., Feinberg, R., Rhee, E., 2004. Relationships and individuals' bank switching behaviour. Journal of Economic Psychology25 (4), 507.

Clemes, M.D., Gan, C. and Zheng, L.Y. (2007a), "Customer switching behaviour in the NewZealand banking industry”, Banks and Banks System, Vol. 2 No. 4, pp. 50-66. Oliver, R. L. (1999). Whence consumer loyalty? Journal of Marketing, 63, 33-44.

Cengiz, E., Ayyildiz, H. and Er, B. (2007), "Effects of image and adverting efficiency on customer loyalty and antecedents of loyalty: Turkish banks sample", Banks and Bank Systems, Vol. 2 No. 1, pp. 56-80.

Caruana, A. (2004), "The impact of switching costs on customer loyalty: a study among corporate customers of mobile telephony", Journal of Targeting, Measurement and Analysis for Marketing, Vol. 12 No. 3, pp. 256-68.

Dacin, P.A., Gunst, R.F., 2005. Spreading the word: investigating antecedents of consumer's positive word-of-mouth intentions and behaviours in a retailing context. Journal of the Academy of Marketing Science 33 (2), 123-138.

Dube, L. and Maute, M. (1996), "The antecedents of brandswitching, brand loyalty and verbal responses to servicefailure", Advances in Services Marketing and Management,Vol. 5, pp. 127-5. 


\section{Al Macrothink}

Journal of Public Administration and Governance ISSN 2161-7104 2014, Vol. 4, No. 2

Doney, P. M., \& Cannon, J. P. (1997). An examination of the nature of trust in buyer-seller relationships. Journal of Marketing, 61(2), 35-51.

Fornell, C., Johnson, M.D., Anderson, E.W., Cha, J. and Bryant, B.E. (1996), “The American customer satisfaction index: nature, purpose and findings", Journal of Marketing, Vol. 60 No. 4 , pp. $7-18$

Fornell, C. (1992). A national customer satisfaction barometer: The Swedish experience. Journal of Marketing, 56(1), 6-21.

Fornell, C. (1992). A national customer satisfaction barometer: The Swedish experience. Journal of Marketing, 56(1), 6-21.

Garbarino, E., \& Johnson, M. S. (1999). The different roles of satisfaction, trust, and commitment in customer relationships. Journal of Marketing, 63(2), 70-87.

Hennig-Thurau, T., \& Klee, A. (1997). The impact of customer satisfaction and relationship quality on customer retention: A critical reassessment and model development. Psychology and Marketing, 14(8), 737-764.

Heide, J.B. and Weis, A.M. (1995), "Vendor consideration and switching behaviour for buyers in high-technology markets", Journal of Marketing, Vol. 59 No. 3, pp. 30-43.

Harrison-Walker, L.J., 2001. The measurement of word-of-mouth communication and investigation of service quality and customer commitment as potential antecedents. Journal of Service Research 4 (1), 60-75.

Hennig-Thurau, T., Gwinner, K.P. and Gremler, D.D. (2002), "Understanding relationship marketing outcomes: an integration of relational benefits and relationship quality", Journal of Service Research, Vol. 5, February, pp. 230-47.

Jones, M.A., Mothersbaugh, D.L. and Beatty, S.E. (2002),"Why customers stay: measuring the underlying dimensions of services switching costs and managing their differential strategic outcomes", Journal of Business Research, Vol. 55No. 6, pp. 441-50.

Jones, M.A., Mothers Baugh, D.L. and Beatty, S.E. (2007),“The positive and negative effects of switching costs on relational outcomes", Journal of Service Research, Vol. 9No. 4, pp. $335-55$

Jones, T. O., \& Sasser, W. E., Jr. (1995). Why satisfied customer defect? Harvard Business Review, 73(6), 88-99.

Keaveney, S. M. (1995). Customer switching behaviour in service industries: An explorative study. Journal of Marketing, 59(2), 71-82.

Keaveney, S. M. (1995). Customer switching behaviour in service industries: An explorative study. Journal of Marketing, 59(2), 71-82.

Lantos, G.P. (1983),"The influence of inherent risk and information acquisition on consumer risk reduction strategies", Journal of the Academy of Marketing Science, Vol. 11 No. 4, pp. 
$358-81$.

Lean, O. K., Zailani, S., Ramayah, T., \& Fernando, Y. (2009). Factors influencing intention to use e-government services among citizens in Mala ysia. International Journal of Information Management, 29(6), 458-475.

Liao, C., Palvia, P., \& Lin, H. N. (2006). The roles of habit and web site quality in e_commerce. International Journal of Information Management, 26(6), 469-483.

Maute, M.F. and Forrester, W.R.J. (1993), "The structure and determinants of consumer complaint intentions and behaviour", Journal of Economic Psychology, Vol. 14 No. 2,pp. 219-47.

Mooradian, T. and Oliver, J. (1997), “I can’t get no satisfaction': the impact of personality and emotion on postpurchase processes", Psychology \& Marketing, Vol. 14 No. 4, pp. 379-93.

Mittal, V., Ross, W. Jr and Baldasare, P. (1998),"The asymmetric impact of negative and positive attribute-level performance on overall satisfaction and repurchase intentions", Journal of Marketing, Vol. 62 No. 1, pp. 33-47.

Morgan, R. M., \& Hunt, S. D. (1994). The commitment-trust theory of relationship marketing. Journal of Marketing, 58(3), 20-38.

Namkung, Y. and Jang, S.C. (2007), "Does food quality really matter in restaurants? it's impact on customer satisfaction and behavioural intentions", Journal of Hospitality and Tourism Research, Vol. 31 No. 3, pp. 387-410

Nguyen, N. and Leblanc, G. (2001), "Corporate image and corporate reputation in customers' retention decisions in services”, Journal of Retailing and Consumer Servcies, Vol. 8 No. 4, pp. 227-36.

Oliver, R. L. (1997). Satisfaction: A behavioural perspective on the consumer. Boston: Irwin McGraw-Hill.

Palvia, P. (2009). The role of trust in e-commerce relational exchange: A unified model. Information \& Management, 46(4), 213-220.

Parasuraman, A., Zeithamal, V. A., \& Berry, L. L. (1988). SERVQUAL: A multiple-item scale for measuring consumer perceptions of service quality. Journal of Retailing, 64, 12-40.

Rust, R.T.,Zahorik, A.J., Keiningham, T.L., 1995. Return on quality (ROQ): making service quality financially accountable. Journal of Marketing 59 (April), 58-70.

Roberts, P.W. and Dowling, G.R. (2002), "Reputation and sustained superior financial performance", Strategic Management Journal, Vol. 23, December, pp. 1077-93.

Roberts, K., Varki, S., \& Brodie, R. (2003). Measuring the quality of relationships in consumer services: An empirical study. European Journal of Marketing, 37(1/2), 169-196. 
Rao, H. (1994), "The social construction of reputation: certification contests legitimation, and the survival of organizations in the automobile industry: 1985-1912", Strategic Management Journal, Vol. 15, pp. 29-44.

Rauyruen, P., \& Miller, K. E. (2007). Relationship quality as a predictor of B2B customer loyalty. Journal of Business Research, 60(1), 21-31.

Swan, J.E. and Oliver, R.L. (1989), "Post purchase communications by consumers", Journal of Retailing, Vol. 65 No. 4, pp. 516-33.

Singh, J.,\&Sirdeshmukh, D. (2000). Agency and trust mechanisms in consumer satisfaction and loyalty judgments. Journal of the Academy of Marketing Science, 28(1), 150-167

Stephens, N. and Gwinner, K.P. (1998), "Why don't some people complain? A cognitive-emotive process model of consumer complaint behavior", Journal of the Academy of Marketing Science, Vol. 26 No. 3, pp. 172-89.

Selnes, F. and Gronhaug, K. (1997), "When does it pay off to exceed customers' expectations? The importance of differentiating should- and could-expectations", working paper of the Norwegian School of Management, Oslo.

Tax, S. S. \& Zeithaml, V.A., Berry, L.L., \& Parasuramann, A. (1996). The behavioral consequences of service quality. Journal of Marketing, 60, 31-46

Wang, Y.G., Lo, H.P. and Hui, Y.V. (2003), "The antecedents of service quality and product reputation: evidence from the bank industry in China", Managing Service Quality, Vol. 13 No. 1, pp. 72-84.

Yuan, J. and Jang, S.C. (2008), "The effects of quality and satisfaction on awareness and behavioural intentions: exploring the role of a wine festival", Journal of Travel Research, Vol. 46, February, pp. 279-88.

Yoon, E., Guffey, H.J. and Kijewski, V. (1993), "The effects of information and company reputation on intentions to buy a business service", Journal of Business Research, Vol. 27, pp. 215-28.

Zeithaml, V.A. \& Bitner, M.J. (2000). Services Marketing: Integrating Customer Focus across the Firm. New York, NY: McGraw-Hill. 